Research article

\title{
ANALYSIS OF GENETIC STRUCTURE OF HUCHEN (Hucho hucho) IN SERBIA INFERRED FROM MITOCHONDRIAL AND NUCLEAR DNA
}

\author{
MARIĆ Saša ${ }^{1 *}$, RAZPET Andrej ${ }^{2}$, NIKOLIĆ Vera ${ }^{1}$, SNOJ Aleš², SIMONOVIĆ \\ Predrag ${ }^{1}$ \\ ${ }^{1}$ Institute of Zoology, Faculty of Biology, University of Belgrade, Belgrade, Serbia; ${ }^{2}$ Department of \\ Animal Science, Biotechnical Faculty, University of Ljubljana, Domžale, Slovenia
}

(Received 8 January; Accepted 9 February 2014)

The purpose of this study was to assess the genetic diversity of Serbian huchen and provide guidelines for conservation and management. Fourteen huchen individuals were collected from six localities. For all individuals the mitochondrial DNA control region and the NADH1 gene were sequenced, and two microsatellite loci were genotyped. Sequencing of two mtDNA loci showed the presence of the same haplotypes (Hh_CR_1 and Hh_ND1_1) in all investigated specimens and the complete absence of genetic variability at inter- and intra-populational level. However, analyzed individuals from Serbia have the largest number of control region repeats (average 8.7) compared to all other huchen populations from the Danube basin. Microsatellite data show that the most of Serbian huchens were placed in the "eastern" cluster except one individual from the Drina River which clustered with "western" samples, most likely a consequence of stocking. In spite of only two loci used, four unique alleles found in the studied Serbian and Drina basin population indicate that the Danube basin may possess more region specific alleles than previously thought, which could be of great importance for efficient species management in the future.

Key words: genetic diversity, Hucho bucho, microsatellite DNA, mitochondrial DNA, Serbia

\section{INTRODUCTION}

The huchen Hucho bucho (L.) is endemic to the Danube drainage [1], and is, together with sister species Hucho taimen (P.), the largest and most endangered member of the family Salmonidae [2]. Hensel and Holčik [3] designated these taxa as subspecies Hucho bucho bucho and $H$. bucho taimen, in spite of their disjunct distribution.

Extant huchen populations are now isolated from each other after losing about twothirds of their former distribution [1]. The main causes for destruction of the huchen's habitat are increased river regulation, damming, industrial and agricultural pollution [1].

* Corresponding author: e-mail: sasa@bio.bg.ac.rs 
Also, genetic contamination, caused by frequent translocations of huchen specimens among different river drainages, additionally endangers the singularity and originality of huchen populations. Although stocking increases local population size, it also represents a serious threat, leading to introgressive hybridization and extinction of autochthonous alleles [4,5].

On the basis of numerous causes, which threaten survival of huchen, the species is listed on the "IUCN Red List of Threatened species" with status EN (Endangered) since 1990 [6], and also stands in the Appendix III of the Bern Convention (Protected Fauna) and Annexes II and IV of the EU Habitat Directive.

Holčik et al. [2] indicates that the Drina River with tributaries holds the most numerous stock of huchen in Europe. Besides the Drina River basin (with the tributaries of Lim, Poblačnica, Vapa, Uvac and Trešnjica) the range of huchen in Serbia also includes $15 \mathrm{~km}$ of the upper Ibar River, while in the Đetinja and Moravica rivers (Zapadna Morava River drainage), huchen was reintroduced from the Drina River [7].

Serbian national legislation listed huchen on the list of protected wild fauna [8] in order to provide adequate management. Also, with the same purpose, two Action plans were realized: "Action Plan for Fisheries Management with Huchen Stocks in Catchments of the Republic of Serbia" [7] and "Research of Life History and Population Traits of Huchen in Serbia" [9]. Minimal landing size was determined as result of huchen growth characteristics [10,11].

Weiss et al. [5] published the preliminary results of investigations on genetic diversity and phylogeographic structure of huchen populations, analyzed two mitochondrial loci (control region and NADH1) and two microsatellite loci in 47 huchen samples from eleven locations across the Danube drainage. Extremely limited and geographically uniform levels of $\mathrm{mtDNA}$ haplotype diversity with only four closely related haplotypes was revealed. Nonetheless, geographic distribution of the control region nucleotide repeats (5 to 10 copies per individual), as well as microsatellite alleles, strongly reject the existence of a single population in the Danube basin and rather supported a largescale structure distinguishing western (Austria and Slovenia) from eastern (Slovakia, Ukraine, Bosnia-Herzegovina and Montenegro) sample sites (ISO 3166-1 three-letter country codes are also used in this paper).

The main aim of this study was to evaluate genetic diversity and phylogeographic structure of huchen populations in Serbia, using two mitochondrial loci (control region and NADH1) and two microsatellite loci (HLJZ003 and HLHZ023). Results generated could contribute to more efficient management of the species in the future.

\section{MATERIAL AND METHODS}

\section{Sampling and DNA isolation}

A total of 14 huchen from six Serbian locations were collected using electrofishing and angling from 2002 until 2007 (Fig. 1). Fin clips were taken and stored in 96\% ethanol. 
Total DNA was isolated from the preserved fin tissue using the Wizard Genomic DNA Purification Kit (Promega), following the supplier's instructions.

Data from reference European populations are from Weiss et al. [5], samples from Drina River (seven individuals from Bosnia and Herzegovina) and Plavsko Lake (two individuals from Montenegro - drainage of Drina River) were analyzed together with 14 samples from this study.

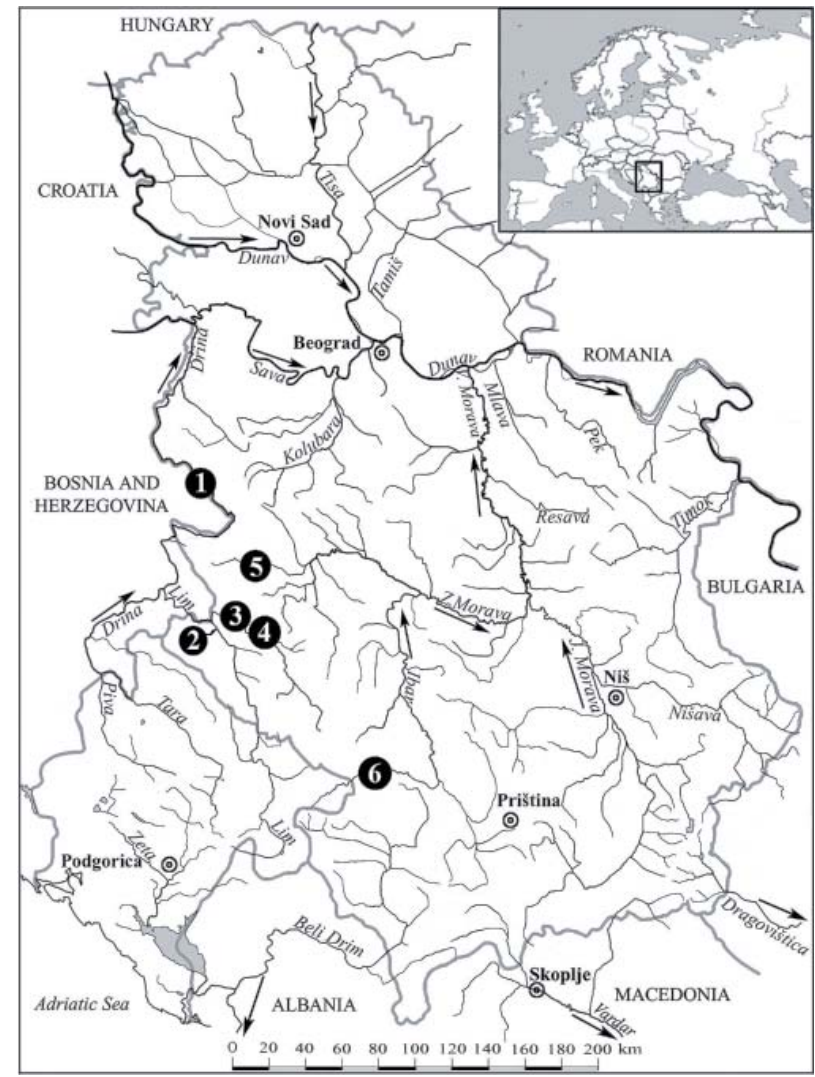

Figure 1. Map of the sampling locations in Serbia with sample sizes $(\mathrm{N})$. 1. Drina River $(\mathrm{N}=5), 2$. Poblačnica River $(\mathrm{N}=2)$, 3. Zlatar Lake $(\mathrm{N}=1)$, 4. Uvac Lake $(\mathrm{N}=2)$, 5. Đetinja River (N=2), 6. Ibar River ( $=2$ )

\section{mIDNA amplification, sequencing and aligning}

Two mtDNA loci, CR and NADH1 were amplified in 14 individuals using polymerase chain reactions (PCR). The CR ( $c a .1500-1650 \mathrm{bp})$ was amplified using primers 28RIBa [12] and HN20 [13]. The NADH1 (ca. 1150 bp) was amplified using primers B1NDF and B1NDR [14]. The PCR amplification conditions were reported in Razpet et al. [15] and Froufe et al. [14]. Amplified DNA fragments were run on a 1.5\% gel and subsequently isolated from the gel using the QIAEX II gel Extraction Kit (QIAGEN). 
Sequencing reactions were prepared using a BigDye Terminator v3.1 Cycle Sequencing Kit (Applied Biosystems) according to the manufacturer's recommendations. The whole CR was sequenced using primers 28RIBa [12], STIF [5], and HN20 [13]. The 5'-end of 811 bp segment of NADH1 was sequenced using primer B1NDF [14]. The amplified, fluorescently labelled and terminated DNA was salt-precipitated and analyzed on an ABI Prism 3130xl Genetic Analyzer.

Sequences of the mtDNA (CR and NADH1) were aligned using the computer program Clustal W [16].

\section{msDNA amplification and GeneScan}

Two microsatellite loci HLJZ003 (bi-nucleotide repeat) and HLJZ023 (tri-nucleotide repeat) were tested in 14 individuals using fluorescently labelled forward primers. PCR amplifications of these loci were conducted according to previously published protocols [5,17]. Aliquots of amplified DNA were mixed with formamide and GeneScan-500 ROX Size Standard (Applied Biosystems), ran on an ABI Prism 3130xl Genetic Analyser and genotyped using GeneMapper Software v4.0.

\section{msDNA data analysis}

Microsatellite allele frequencies, number of alleles per locus, expected $\left(\mathrm{H}_{\mathrm{e}}\right)$ and observed $\left(\mathrm{H}_{\mathrm{o}}\right)$ heterozygotes were calculated with GENETIX 4.04 [18]. FSTAT 2.9.3.2 [19] was used to detect deviations from Hardy-Weinberg expectations (HWE) and pair-wise $\mathrm{F}_{\mathrm{ST}}$ values, all based on 1000 permutations. Genetic relationships between individuals were estimated as the proportion of shared alleles at each locus, i.e. allele sharing distances $\left(\mathrm{D}_{\mathrm{AS}}\right)$ [20]. A matrix of $\mathrm{D}_{\mathrm{AS}}$ was used to construct Neighbour-Joining tree of individuals with POPULATIONS software [21].

Population structure was inferred using the STRUCTURE [22], a program that runs Markov chain Monte Carlo (MCMC) simulations to partition individuals into $\mathrm{K}$ clusters. Basic assignment criteria are the minimization of Hardy-Weinberg and linkage disequilibria [22]. For runs estimating $\ln \operatorname{Pr}(\mathrm{X} \mid \mathrm{K})$ under a certain $\mathrm{K}$, runs with 100000 steps after 100000 burn-in steps were made, repeated seven times for each K. We applied the $\Delta \mathrm{K}$ method [23] to estimate the most probable $\mathrm{K}$ and a method which includes sample group information [24].

\section{RESULTS}

\section{mtDNA sequence analysis}

Sequencing of two mtDNA loci (control region, 834 bp with addition of 8-10 repetitions of $82 \mathrm{bp}$ each, and NADH-1, $811 \mathrm{bp}$ ) showed the presence of the same haplotypes (Hh_CR_1 - EU729360 and Hh_ND1_1 - EU729362) in all investigated specimens. 


\section{msDNA analysis}

Microsatellite diversity was compared between two groups, first including all samples from Serbia (this study) and samples from the Drina River and Plavsko Lake [5]. Samples were merged because two locations from Weiss et al. [5] belong to the Drina River drainage. The other group consists of all other locations from Weiss et al. [5]. Differences between both groups (Table 1) arise mainly from the allele 264 of the HLJZ023 locus, which can be found in high frequencies over geographically distant locations, but is absent in the western cluster (SVN/AUT). Altogether there are four alleles [336, 356, 362 (Drina and Ibar basin) and 360 (Ibar basin)] of HLJZ003 locus that are unique to the analyzed area with a combined frequency of 0.24 within the group. Both groups are marginally in HWE (95\% significant) with highly significant $(>99.99 \%) \mathrm{F}_{\mathrm{ST}}$ value of 0.125 . Previously observed division of huchen into western and eastern clusters was confirmed with additional samples using individuals' tree based on $\mathrm{D}_{\mathrm{AS}}$ genetic distances (Fig. 2). Two samples that were clustered with samples of different geographic origin (marked on Fig. 2) in $\mathrm{D}_{\mathrm{AS}}$ tree were placed in clusters matching Weiss et al. [5] division using STRUCTURE (Fig. 3). Taking into account sample group information [24] had no effect on Structure results.

Table 1. Population parameters for the Serbia - Drina drainage and all other locations. He and Ho - expected and observed heterozygotes; all Fis values were statistically significant (95\%), therefore not deviating from the Hardy-Weinberg equilibrium

\begin{tabular}{|c|c|c|c|c|c|c|c|c|c|}
\hline \multirow[b]{2}{*}{ Locus } & \multirow[b]{2}{*}{$\begin{array}{c}\text { Allele } \\
\text { Size }\end{array}$} & \multicolumn{4}{|c|}{$\begin{array}{c}\text { SRB, MNT, Drina (BIH) } \\
23 \text { samples }\end{array}$} & \multicolumn{4}{|c|}{$\begin{array}{l}\text { AUT, SVK, SVN, UKR, Vrbas (BIH) } \\
38 \text { samples }\end{array}$} \\
\hline & & $\begin{array}{c}\text { Allele } \\
\text { Frequencies }\end{array}$ & $\mathbf{H}_{\mathrm{E}}$ & $\mathbf{H}_{\mathrm{o}}$ & $F_{\text {is }}$ & $\begin{array}{c}\text { Allele } \\
\text { Frequencies }\end{array}$ & $\mathrm{H}_{\mathrm{E}}$ & $\mathbf{H}_{\mathrm{o}}$ & $F_{\text {is }}$ \\
\hline \multirow[t]{7}{*}{ HLJZ023 } & & & 0.2987 & 0.3034 & 0.003 & & 0.7559 & 0.3947 & 0.488 \\
\hline & 258 & 0.1304 & & & & 0.2632 & & & \\
\hline & 264 & 0.8261 & & & & 0.3026 & & & \\
\hline & 267 & 0 & & & & 0.0132 & & & \\
\hline & 270 & 0 & & & & 0.2632 & & & \\
\hline & 273 & 0 & & & & 0.0526 & & & \\
\hline & 279 & 0.0435 & & & & 0.1053 & & & \\
\hline \multirow[t]{14}{*}{ HLJZ003 } & & & 0.7703 & 0.5217 & 0.342 & & 0.8587 & 0.4737 & 0.459 \\
\hline & 308 & 0.1304 & & & & 0.0263 & & & \\
\hline & 312 & 0.4130 & & & & 0.2105 & & & \\
\hline & 314 & 0 & & & & 0.1447 & & & \\
\hline & 322 & 0.0217 & & & & 0.0395 & & & \\
\hline & 326 & 0.0870 & & & & 0.1579 & & & \\
\hline & 336 & 0.0652 & & & & 0 & & & \\
\hline & 338 & 0.1087 & & & & 0.1316 & & & \\
\hline & 342 & 0 & & & & 0.1447 & & & \\
\hline & 346 & 0 & & & & 0.0789 & & & \\
\hline & 356 & 0.1304 & & & & 0 & & & \\
\hline & 360 & 0.0217 & & & & 0 & & & \\
\hline & 362 & 0.0217 & & & & 0 & & & \\
\hline & 374 & 0 & & & & 0.0658 & & & \\
\hline
\end{tabular}




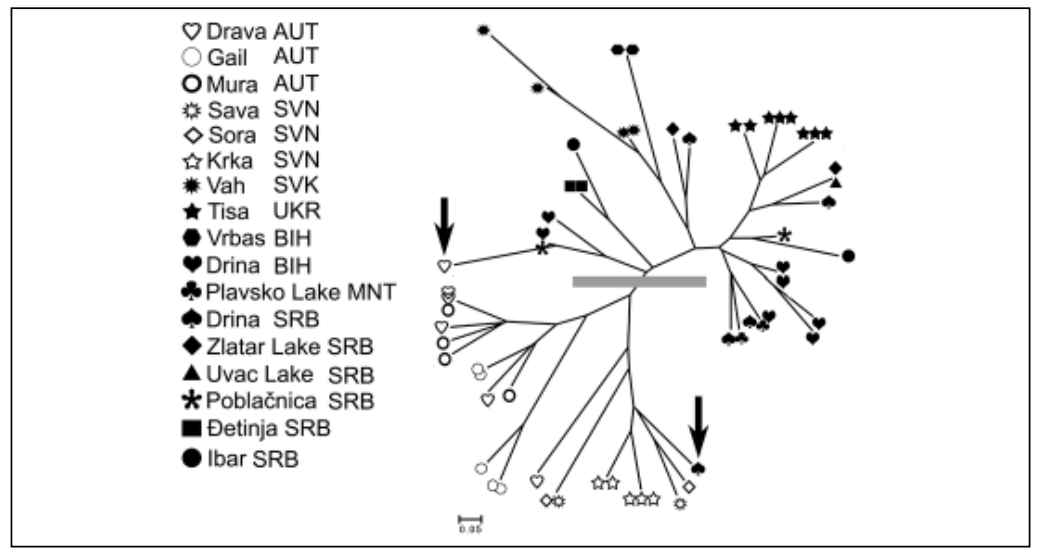

Figure 2. The unrooted Neighbor-Joining tree of individuals based on allele sharing distances $\left(\mathrm{D}_{\mathrm{AS}}\right)$ and inferred from microsatellite data. Samples from Slovenia and Austria (white symbols), Serbia and Drina basin and other lower Danube locations (black symbols) form two clusters as in Weiss et al. (5), indicated by a grey bar. Arrows indicate two individuals that fall in clusters not matching their origin

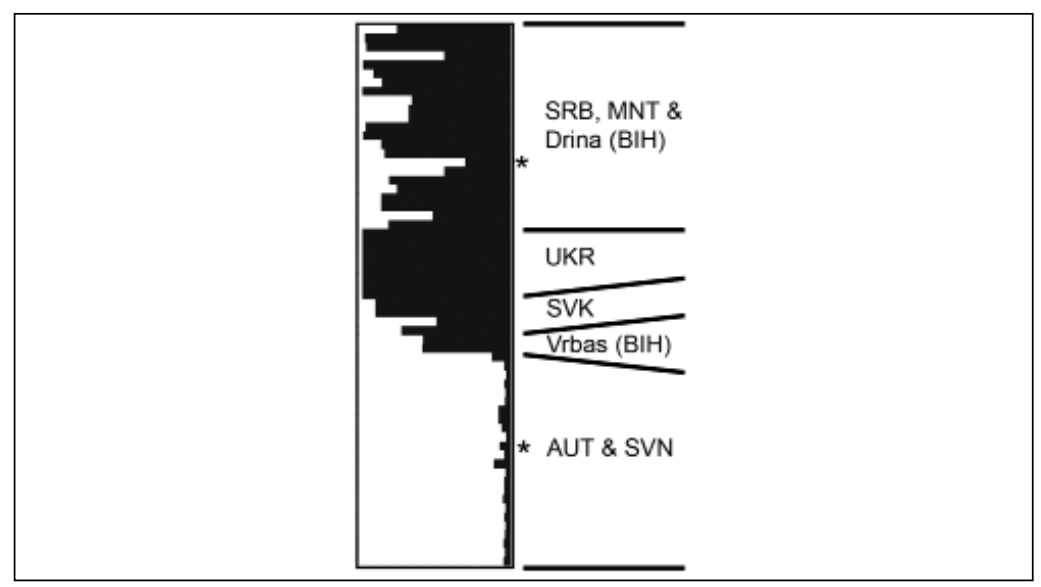

Figure 3. Structure plot of samples with the most probable number of clusters $(K=2)$. For each sample the amount of color in a horizontal bar represents the relative contribution of a given cluster. Based on allele sharing distances $\left(\mathrm{D}_{\mathrm{AS}}\right)$, the two individuals marked by asterisks fall in clusters not matching their origin (see Fig. 2)

\section{DISCUSSION}

Inter- and intra-populational diversity of huchen populations on the territory of Serbia cannot be obtained through analyzing only mtDNA because of insufficient phylogenetic information provided by this molecule. The only polymorphism found in mtDNA is limited to the number of CR repeats. When comparing the number of repeats with Weiss et al. [5], huchen from Serbia have on average 8.7 CR repeats, 
while samples from Western Europe have 7.1, and all samples from the eastern areas have 8.2. However, since mutational regimes that lead to formation of repeats are not known, these repeats are not used in phylogenetic analyses $[5,25]$.

Microsatellite data confirm the division between western (AUT/SVN) and eastern (all other locations studied) huchen populations. Also, microsatellite data show that even in a geographically confined region of Serbia and the River Drina drainage, the level of genetic diversity is comparable to the rest of the Danube drainage. In spite of only two used loci, three unique alleles found in the studied Serbian and a fourth in the Montenegrin part (Plavsko Lake) of the Drina basin population, indicate that the Danube basin may possess more region specific alleles than previously thought.

Tree of individuals based on genetic distance $\mathrm{D}_{\mathrm{AS}}$ (Fig. 2) reveals two samples in subtrees not matching their origin. Individual from the Drina River in AUT/SVN sub-tree could be a consequence of non-documented stocking in the Drina basin. According to testimonies from members of the Anglers' Association "Mladica" from Bajina Bašta stocking of both huchen and grayling (Thymallus thymallus) from Slovenia occurred in the 1980's (for grayling see also 26). Stocking was confirmed by STRUCTURE analysis, where this individual has inferred ancestry of $70 \%$ to western cluster, highest among all samples originating from lower Danube basin (Fig. 3). A sample from Austria that was placed in the "eastern" sub-tree does not stand out from other western samples after STRUCTURE analysis; however that can be explained by its genotype with alleles that are present in both sub-trees with high frequencies. Both samples have very common mtDNA haplotypes that prevent clear identification of stocked individuals.

Despite the generally low level of molecular diversity of huchen in the Danube River basin, the detected genetic structure must be taken into account in future fish management measures of huchen stock throughout its areal. Although we currently possess preliminary information on the genetic structure of populations of huchen from Serbia, the presence of three unique alleles and a larger number of CR repeats certainly indicate that the analyzed populations deserve the implementation of conservation activities. Therefore, two recommendations for future management should be followed: 1 . avoiding inter-basin fish transportation activities; 2 . local stocks should be used for restocking managed populations, with prior obligatory genotyping broodstock individuals to prevent further spreading of detected non-native genetic material.

\section{Acknowledgement}

This research was supported by the Ministry of Education and Science (grants No. 173025 and 173045), Ministry of Environment Protection and Spatial Planning of the Republic of Serbia (grant "Research of Life History and Population Traits of Huchen in Serbia") and Slovenian Research Agency (grant No. Z4-3667). 


\section{REFERENCES}

1. Holčík J: Conservation of the huchen, Hucho hucho (L.), (Salmonidae) with special reference to Slovakian rivers. J Fish Biol 1990, 37(Suppl. A):113-121.

2. Holčík J, Hensel K, Nieslanik J, Skácel L: The Eurasian huchen, Hucho hucho: largest salmon of the world. Perspect Vertebr Sci 1988, 5:239.

3. Hensel K, Holčík J: On the identity of Hucho hucho and Hucho taimen (Pisces, Salmonidae). Folia Zool 1983, 32(1):67-83.

4. Hindar K, Ryman N, Utter FM: Genetic effects of cultured fish on natural fish populations. Can J Fish Aquat Sci 1991, 48:945-957.

5. Weiss S, Marić S, Snoj A: Regional structure despite limited mtDNA sequence diversity found in the endangered Huchen, Hucho hucho (Linnaeus, 1758), Hydrobiologia 2011, 658:103-110.

6. IUCN Red List of Threatened Species: Version 2013.2. [www.iucnredlist.org]

7. Hegediš A, Mićković B, Cvijanović G: Akcioni plan upravljanja mladicom u ribolovnim vodama Republike Serbije. Beograd: Centar za multidisciplinarne studije Univerziteta u Beogradu; 2005, 52 pp.

8. Anonymous: Regulation on the designation and protection of strictly protected and protected wild fauna, flora and fungi species. Službeni glasnik Republike Srbije;2010, 5\& 47/2011.

9. Marić S, Nikolić V, Paunović M, Simonović P: Istraživanje životnog ciklusa i populacionih karakteristika mladice u Srbiji. Beograd: Univerzitet u Beogradu - Biološki fakultet i Ministarstvo životne sredine i prostornog planiranja; 2009, 79 pp.

10. Simonović P, Marić S, Nikolić V: Growth characteristics of huchen Hucho hucho (L.) from Rivers Drina, Una and Sana. Acta Biologica Iugoslavica - Ekologija Belgrade 2000, 35:123-126.

11. Simonović P, Nikolić V, Tošić A, Marić S: Length-weight relationship in adult huchen Hucho hucho (L., 1758) from Drina River, Serbia, Biol Brat 2011, 66(1):156-159.

12. Snoj A, Jug T, Melkič E, Sušnik S, Pohar J, Dovč P, Jesenšek D, Budihna, N: Mitochondrial and microsatellite DNA analysis of marble trout in Slovenia. J Freshw Biol 2000, 29:5-11.

13. Bernatchez L, Danzmann RG: Congruence in control-region sequence and restriction-site variation in mitochondrial DNA of brook charr (Salvelinus fontinalis Mithcill). Mol Biol Evol 1993, 10(5):1002-1014.

14. Froufe E, Alekseev S, Knizhin I, Weiss S: Comparative mtDNA sequence (control region, ATPase6 and NADH-1) divergence in Hucho taimen (Pallas, 1773) across four Siberian river basins. J Fish Biol 2005, 67:1040-1053.

15. Razpet A, Sušnik S, Jug T, Snoj A: Genetic variation among trout in the River Neretva basin, Bosnia and Herzegovina. J Fish Biol 2007, 70(A):94-110.

16. Thompson JD, Higgins DG, Gibson TJ: Clustal W: improving the sensitivity of progressive multiple sequence alignment through sequence weighting, position-specific gap penalties and weight matrix choice. Nucl Acids Res 1994, 22:4637-4680.

17. Guangxiang T, Youyi K, Jiasheng Y, Liqun L, Xiaowen S: Isolation of microsatellite DNA and analysis on genetic diversity of endangered fish, Hucho taimen (Pallas). Mol Ecol Notes 2006, 6:1099-1101.

18. Belkhir K, Borsa P, Chikhi L, Raufaste N, Bonhomme F: GENETIX v. 4.04. Logiciel sous WindowsTM pour la Génétique des Populations. Montpellier: Université Montpellier 2, Laboratoire Génome et Population, 2003. 
19. Goudet J: FSTAT. A program to estimate and test gene diversities and fixation indices (version 2.9.3.2), 2002. [http://www2.unil.ch/popgen/softwares/fstat.htm]

20. Bowcock AM, Ruiz-Linares A, Tomfohrde J, Minch E, Kidd JR, Cavalli-Sforza LL: High resolution of human evolutionary trees with polymorphic microsatellites. Nature 1994, 368:455-457.

21. Langella O: Populations 1.2.28. Logiciel de génétique des populations. Laboratoire Populations, génétique et évolution, CNRS UPR 9034, Gif-sur-Yvette, 2002. [http://www. cnrs-gif.fr/pge/]

22. Pritchard JK, Stephens M, Donnelly P: Inference of population structure using multilocus genotype data. Genetics 2000, 155:945-959.

23. Evanno G, Regnaut S, Goudet J: Detecting the number of clusters of individuals using the software STRUCTURE: a simulation study. Mol Ecol 2005, 14:2611-2620.

24. Hubisz MJ, Falush D, Stephens M, Pritchard JK: Inferring weak population structure with the assistance of sample group information. Mol Ecol Resour 2009, 9(5):1322-1332.

25. Sušnik S, Snoj A, Wilson IF, Mrdak D, Weiss S: Historical demography of brown trout (Salmo trutta) in the Adriatic drainage including the putative S. letnica endemic to Lake Ohrid. Mol Phylogenet Evol 2007, 44:63-76.

26. Marić S, Razpet A, Nikolić V, Simonović P: Genetic differentiation of European grayling (Thymallus thymallus) populations in Serbia, based on mitochondrial and nuclear DNA analyses. Genet Sel Evol 2011, 43:2.

\title{
ANALIZA GENETIČKE STRUKTURE MLADICE (Hucho hucho) U SRBIJI NA OSNOVU MITOHONDRIJSKE I JEDARNE DNK
}

\author{
MARIĆ Saša, RAZPET Andrej, NIKOLIĆ Vera, SNOJ Aleš, SIMONOVIĆ Predrag
}

Cilj ovoga rada je bio da se izvrši procena genetičkog diverziteta mladice u Srbiji, i da se na osnovu dobijenih rezultata daju preporuke za buduće očuvanje i upravljanje fondom mladice. Za ovu svrhu sakupljeno je 14 jedinki sa šest lokaliteta. Za sve sakupljene jedinke sekvencirana je kontrolna regija, NADH1 gen mitohondijske DNK i genotipizirana su dva mikrosatelitska lokusa. Sekvenciranjem dva mtDNK lokusa utvrđeno je prisustvo istih haplotipova (Hh_CR_1 i Hh_ND1_1) kod svih ispitanih jedinki, odnosno, potpuno odsustvo genetičke varijabilnosti na inter- $\mathrm{i}$ intra-populacionom nivou. Međutim, analizirane jedinke iz Srbije karakterišu se najvećim brojem ponovaka kontrolne regije (prosečno 8,7), u poređenju sa svim ostalim populacijama mladice iz dunavskog sliva. Analizom mikrosatelitskih podataka, utvrđeno je da se gotovo sve jedinke iz Srbije svrstavaju u "istočnu” grupu, izuzev jedne jedinke iz Drine, koja je svrstana sa "zapadnim" uzorcima, što je najverovatnije posledica poribljavanja. Kod analiziranih jedinki sa teritorije Srbije i iz celokupnog sliva Drine pronađena su četiri jedinstvena alela, uprkos analizi samo dva mikrosatelitska lokusa. Dobijeni rezultati ukazuju da dunavski sliv može posedovati više regionalno specifičnih alela nego što se ranije smatralo, što bi moglo biti od velikog značaja za uspešno upravljanje fondom mladice u budućnosti. 